\title{
EDITORIAL
}

\section{Conhecer a história é um compromisso de todos}

\author{
Knowing history is everyone's commitment
}

\author{
Telmo P. Bonamigo*
}

Para refrescar a memória dos mais antigos e para esclarecer aos mais jovens que chegaram à SBACV nos últimos anos, fui convidado a escrever um editorial comemorativo ao quinto ano de existência do $\mathrm{J}$ Vasc $\mathrm{Br}$, agora J Vasc Bras, e o faço com muita alegria.

Devemos inicialmente contar como ele nasceu. A SBACV já tivera duas revistas previamente, ambas criadas e mantidas por pessoas físicas, ligadas à SBACV, mas sem que esta tivesse ingerência maior ou menor sobre a gestão das mesmas. Obviamente que não tinha sentido a SBACV "ser madrasta podendo ser mãe" de uma publicação oficial.

Assim, no processo eleitoral que culminou com a eleição de Marcio Leal Meirelles, o item mais importante da plataforma foi a criação de uma revista oficial. A SBACV seria a detentora de sua marca, da responsabilidade da linha editorial, dos "bônus ou ônus" dela advindos e dos méritos, que seriam distribuídos para todos os associados. Pessoalmente, fui encarregado desta missão, sendo Editor-Chefe por 40 meses. Recebi o apoio continuado da Diretoria e de grande número de colegas do Conselho Editorial, revisores e principalmente de autores. E assim foi feito.

Após esta introdução, insiro o texto do primeiro editorial que escrevi por ocasião do lançamento do $\mathbf{J}$

\footnotetext{
* Professor adjunto, Cirurgia Vascular, Fundação Faculdade Federal de Ciências Médicas de Porto Alegre (FFFCMPA), Porto Alegre, RS. Chefe, Serviço de Cirurgia Vascular, Santa Casa de Porto Alegre, Porto Alegre, RS. Presidente, Academia Sul-RioGrandense de Medicina.

J Vasc Bras 2007;6(2):110-111.

Copyright $\odot 2007$ by Sociedade Brasileira de Angiologia e de Cirurgia Vascular
}

Vasc Br. Ali estão registrados todos os princípios que haveriam de nortear a gestão do mesmo.

Há muitos anos vem sendo constatada uma discrepância entre a densidade científica dos colegas associados da Sociedade Brasileira de Angiologia e Cirurgia Vascular e o que este grupo tem publicado. Há várias causas que conduziram a esse fato, embora esta não seja a melhor hora para tentar identificá-las. Este é o momento de nos rejubilarmos pelo lançamento do primeiro número do Jornal Vascular Brasileiro ( $J$ Vasc Br). É a hora de somarmos esforços para dar continuidade editorial ao projeto anterior e, com a criação do $\mathrm{J}$ Vasc $\mathrm{Br}$, abrir oportunidades para que todos tenham à sua disposição o espaço para a publicação dos seus trabalhos sempre que atenderem as normas básicas e passarem pela análise dos consultores.

Na fase inicial, contamos com a demanda de trabalhos por convite, mas já temos recebido manifestações espontâneas significativas. Esperamos ainda a contribuição dos serviços de residência em cirurgia vascular e dos cursos de pós-graduação, com seu enorme potencial de publicações. Da mesma forma, visamos divulgar o material dos serviços de cirurgia vascular, com grande tradição assistencial.

Outra fonte importante deverão ser as disciplinas de cirurgia vascular das várias faculdades do Brasil, além dos centros regionais de referência de cirurgia vascular.

Finalmente, também contamos com a contribuição individual dos cirurgiões e clínicos que prestam assistência médica individualizada, mas que, ao longo dos anos, acumularam grande experiência, que há de ser útil para todos nós. 
A tarefa de editar o J Vasc Br não é só um compromisso do seu Corpo Editorial e da Diretoria da SBACV, que viabilizou sua criação, mas sim um compromisso que deve ser entendido como uma tarefa de todos os associados. E, neste momento, formulamos o convite para que todos se engajem nesse processo. As normas para publicação são as recomendadas pela Convenção de Vancouver, $e$ é muito importante que sejam seguidas à risca para simplificar o processo de seleção e revisão dos trabalhos. Vamos perseguir a indexação da Revista, o que será uma tarefa difícil, mas não impossível. Assim, queremos dar atenção especial à publicação de artigos originais, que deverão constituir mais de 50\% do material editado. Os relatos de casos deverão ser limitados a dois ou três, mas já temos uma forma para acolher os que ultrapassarem esta quota.

O J Vasc Br deverá publicar, de forma preferencial, todos os fóruns oficializados pela SBACV. Neste número já está sendo publicado o Fórum Cirurgia Endovascular: Qual o papel atual na nossa especialidade?, coordenado pelos colegas Prof. Pedro Puech Leão e Solange S. M. Evangelista. Também serão publicadas as diretrizes para a prevenção de tromboembolia venosa - Prevention of Venous Thromboembolism - Guidelines compiled in accordance with the scientific evidence under the auspices of the Cardiovascular Disease Educational and Research Trust, and the International Union of Angiology. A autorização para publicar as diretrizes foi obtida junto ao Editor Prof. A. Nicolaides, por empenho especial do colega Márcio Castro e Silva, a quem o J Vasc $\mathrm{Br}$ agradece, esperando contar com outras contribuições desta ordem.

Outra inovação muito importante que gostaríamos de comunicar é a versão dos textos para o inglês a ser divulgada pela Internet no site da SBACV. Dessa forma, nossos autores poderão ter seus trabalhos conhecidos em todo o mundo. A Internet também poderá acolher um número maior de relatos de casos, permitindo a publicação de observações interessantes. Informamos, ainda, que os autores que, por motivos especiais, desejarem que seu artigo original seja impresso em inglês, podem apresentá-lo para análise já diretamente nessa língua.

$\dot{E}$ importante enfatizar que a Diretoria atual da $S B A C V$ considera o $\mathrm{J}$ Vasc Br como um investimento, razão pela qual ele será distribuído gratuitamente, não apenas aos nossos associados, mas também a colegas de outras especialidades, com o objetivo de tornar nossa especialidade mais conhecida e valorizada. Assim, não esqueça de recomendar e enviar o endereço de pelo menos dois colegas de outras áreas que possam ter interesse na leitura do J Vasc Br.

Finalizando, agradecemos a todos os colegas do Conselho Editorial dispostos a colaborar e a todos os associados que hão de tornar o J Vasc Br um veículo de divulgação da nossa especialidade que esteja à altura da nossa Sociedade.

Depois de 40 meses, deixei a posição de Editor e acompanho com meu apoio e participação ativa, como autor e revisor.

Agora que a criança pode caminhar, é chegado o momento de consolidação do J Vasc Bras, com o cuidado de manter-se a liberdade editorial, longe do controle corporativo e próximo do interesse maior dos associados e dos pacientes.

Minhas palavras sempre foram e serão de estímulo a que cada associado e cada serviço participem ativamente do processo editorial, enviando os seus trabalhos para prestigiar e fazer crescer o J Vasc Bras.

Concluo com a certeza de que todos os associados da SBACV podem sentir-se orgulhosos pela semente que foi plantada e germinou, como nova árvore cresceu e agora precisa consolidar-se de forma definitiva, com a ajuda de todos. 